\title{
MARXISMO E RELIGIÃO OU O ATEÍSMO NO CRISTIANISMO: A ANÁLISE DE ERNST BLOCH
}

\author{
Marta Maria Aragão Maciel ${ }^{1}$ \\ Antonio Rufino Vieira ${ }^{2}$
}

\section{Resumo:}

No deslindar da reflexão acerca da relação entre utopia e religião, Ernst Bloch pode ser apontado como um autor segundo o qual o ateísmo é a verdade da religião, tal como pode sugerir o título de seu importante trabalho $O$ ateísmo no cristianismo (1968). De fato, a questão da religião é tão relevante como experiência utópica que várias das obras de Ernst Bloch abordam o tema, encontrando-se também presente em obras como $O$ Espírito da utopia (1918), Thomas Münzer: teólogo da revolução (1921), e na sua mais importante e conhecida obra, $O$ Princípio esperança (1954-1959). Pretendemos refletir o significado da relação entre marxismo e religião no pensamento de Ernst Bloch, relação essa que nos permitirá compreender como é apenas aparente o paradoxo existente ao nos reportarmos ao autor de Herança dessa época como um "marxista cristão", ou como um pensador "ateu religioso", ou mesmo "ateu cristão". Para tanto, necessitamos refletir a relação estabelecida entre utopia e religião, central na obra do autor aqui em questão, cujos lineamentos busca-se vincular diretamente ao marxismo. Como parte da superestrutura, a religião ocupa, com efeito, lugar central na preocupação filosófica de Ernst Bloch, de modo a não podermos desconsiderar essa experiência utópica que ocupa espaço tão relevante em sua produção teórica.

Palavras-chave: Ernst Bloch. Marxismo. Religião. Ateísmo. Alienação.

\section{MARXISM AND RELIGION OR ATEISM IN CHRISTIANITY : ACCORDING TO ERNST BLOCH}

\begin{abstract}
:
In unraveling the reflection about the relationship between utopia and religion, Ernst Bloch can be pointed out as an author according to which atheism is the truth of religion, as suggested by the title of his important work, Atheism in Christianity (1968). In fact, the question of religion is so relevant as a utopian experience that several of Ernst Bloch's works address the theme, and are also present in works such as The Spirit of Utopia (1918), Thomas Münzer as Theologian of Revolution (1921), and in his most important and well-known work, The Principle of Hope (1954-1959). We intend to reflect the real meaning of the relationship between Marxism and religion, through which we will understand the apparent paradox presented when we report to Ernst Bloch as a "Christian Marxist", or "religious atheist", or "Christian atheist". Therefore, we need to reflect the relationship established between utopia and religion, which is central to the work of the aforementioned author, whose guidelines seek to link directly to Marxism. Finally, as part of the superstructure, religion occupies a central place in Ernst Bloch's philosophical concern, so that we cannot ignore this utopian experience that occupies such a relevant space in his theoretical production.
\end{abstract}

Keywords: Ernst Bloch. Marxism. Religion. Atheism. Alienation.

1 Graduada em Filosofia pela Universidade Estadual do Ceará. Mestre em Filosofia pela Universidade Federal da Paraíba. Doutora em Filosofia pelo Programa Integrado de Pós-graduação em Filosofia UFPB/UFPE/UFRN. Membro do GEFICS (Grupo de pesquisa em Filosofia e crítica social/UFPB). E-mail: maciel_mart@yahoo.com.br.

2 Professor Titular aposentado da UFPB. Doutor em Filosofia pela Universidade Federal do Rio de Janeiro. É membro dos GT's da ANPOF: "Marxismo" e "Filosofia na América Latina, Filosofia da Libertação e pensamento descolonial”. E-mail: arufino.vieira@gmail.com. 


\section{Introdução}

Somente um ateu pode ser um bom cristão [...]. Somente um cristão pode ser um bom ateu (Bloch, 2016, p. 153).

Certamente a relação entre marxismo e religião é bastante complexa. Em entrevista a José Marchand, a propósito da relação entre marxismo e religião, Ernst Bloch faz o seguinte questionamento: "Por que a Bíblia foi, no contexto dos séculos XV e XVI na Alemanha, na França, na Inglaterra, na Itália e na maior parte das guerras camponesas, aquilo que $O$ Capital de Marx foi ulteriormente, ou seja, um livro fundamental que serviu de modelo?” (Bloch, 2016, p. 153). Tal questão é a que tentaremos responder, pois a partir dela poderemos compreender a associação feita por Bloch entre utopia e religião, afirmação no mínimo incomum na tradição marxista.

Analisaremos a abordagem da análise blochiana da relação entre marxismo e religião a partir de três momentos. No primeiro, destacaremos a importância da crítica de Feueubarch à religião, dando enfoque à questão de ser a religião um produto humano histórico-social; no segundo, destacaremos a presença simbólica da teologia da revolução defendida, teórica e praticamente, por Thomas Münzer, no século XVI, numa tentativa (herética) de retorno ao cristianismo primitivo; no terceiro momento, veremos como Bloch anuncia uma nova antropologia da religião, uma antropologia distinta daquela de Feuerbach. Mesmo reconhecendo que as igrejas estatutárias modificaram os ideais primitivos da comunidade utópico-cristã, atendendo aos interesses das classes dominantes, Ernst Bloch busca pensar dialeticamente a relação entre a religião, criada historicamente pelos homens, e o marxismo, a partir da política engendrada pela luta de classes.

\section{Ernst Bloch, leitor de Ludwig Feuerbach : a religião, ópio do povo?}

Ernst Bloch comparece como leitor de Ludwig Feuerbach, com quem estabelece frequentemente uma relação de proximidade, bem como de afastamento. Aliás, podemos afirmar que uma reflexão crítica acerca do legado religioso, tal como por ele realizado, somente pode alcançar "sua potencialidade crítica, sua oposição à alienação, via Marx e Feuerbach" (Bloch, 1978, p. 80). Desse modo, no entender de Bloch, o trabalho de Ludwig Feuerbach foi fundamental para que os conteúdos religiosos retornassem do céu à terra, de

\begin{tabular}{|l|l|l|l|l|}
\hline Govista Qialectus & Ano 10 & n. 21 & Janeiro - Abril 2021 & p. $136-154$ \\
\hline
\end{tabular}


modo a mostrar que o segredo da religião é o próprio ateísmo ou, na linha da produção teórica do filósofo do século XIX, a verdade da religião é a antropologia.

Ludwig Feuerbach, "esse ateísta tão significativo" (Ernst Bloch, 2006b, p. 369), tomou como elemento central de sua filosofia a crítica ao idealismo hegeliano. Na raiz de sua crítica veemente ao autor do famoso Fenomenologia do espírito encontrava-se um materialismo fundado na afirmação de que a filosofia devia partir do real mesmo, anunciando um pensamento que se apresenta como distinto das filosofias anteriores. Em suas Teses provisórias para a reforma da filosofia, Feuerbach escreve precisamente que "o começo da filosofia não é Deus, não é o absoluto ou a ideia - o começo da filosofia é o finito, o determinado, o real" (Feuerbach, 2002, p. 24).

A reflexão feuerbachiana é fortemente marcada pela afirmação do primado filosófico da sensibilidade. No dizer do pensador alemão, "a afecção precede o pensamento" (Ibid., p. 25). É nessa perspectiva que o humanismo sensualista de Feuerbach criticou fortemente o que chamou de especulação absoluta, imaterial, cujo exemplo máximo teria sido a filosofia de Hegel: "ao fundar todo o seu sistema em atos de abstração, a filosofia hegeliana alienou o homem de si mesmo" (Ibid., p. 22).

Ainda que reconhecendo os limites do materialismo sensualista de Feuerbach, Marx enfatizou a relevância de seu pensamento, particularmente sua luta contra a alienação do homem. Na filosofia feuerbachiana, tal alienação consiste no processo mediante o qual os homens abstraem sua essência e projetam-na em uma realidade exterior. Como escreve Feuerbach, "abstrair significa pôr a essência da natureza fora da natureza, a essência do homem fora do homem, a essência do pensamento fora do ato de pensar" (Ibid., p. 22).

É na luta contra a alienação e em nome da afirmação do homem real, sensível, que se inscreve a crítica antropológica à religião no pensamento de Feuerbach. Em A essência do cristianismo, o autor alemão pondera que a espécie humana tem consciência de si como gênero, representando Deus nada mais que a objetivação da espécie humana, de seus atributos, em um ser exterior. Escreve Feuerbach: "O objeto do homem nada mais é que a sua própria essência objetivada [...]. A consciência de deus é a consciência que o homem tem de si mesmo, o conhecimento de Deus o conhecimento que o homem tem de si mesmo" (Feuerbach, 2007, p. 44).

Assim, transformar a religião em antropologia significaria concluir no ateísmo o segredo da religião. Conforme resumiu Marx acerca do intuito da filosofia de Feuerbach, tratava-se para este pensador de superar a alienação "dissolvendo a essência religiosa na

\begin{tabular}{|c|c|c|c|c|}
\hline Qovista Dialectus & Ano 10 & n. 21 & Janeiro - Abril 2021 & p. $136-154$ \\
\hline
\end{tabular}


essência humana" (Marx, 1996, tese 6). Tal foi o projeto do humanismo feuerbachiano. Todavia, o autor do século XIX não foi um pensador que se ocupou pura e simplesmente de negar a existência objetiva de Deus. Tratava-se, ao descobrir a antropologia como segredo da religião, de desvendar o próprio homem escondido sob as vestes de um mundo sagrado. É nessa perspectiva que, segundo Bloch,

Feuerbach e, antes dele, em alguns aspectos, Hegel, apenas levaram até o fim o que já estava enunciado na pergunta: cur Deus homo? Feuerbach fez os conteúdos religiosos retornarem do céu para o ser humano, de tal maneira que o ser humano não foi criado à imagem fiel de Deus, mas Deus à imagem fiel do ser humano, mais exatamente, à imagem do respectivo modelo ideal de ser humano (Bloch, 2006b, p. 368).

$\mathrm{Na}$ base desse desvelamento da religião tal como realizado por Feuerbach, Ernst Bloch lê uma guinada filosófico-religiosa. Ser o coveiro da religião era, segundo ele, uma tarefa fácil cem anos depois de Voltaire e Diderot. Não se tratava, logo, meramente de afirmar o ateísmo. O elemento central da filosofia feuerbachiana, cuja herança é central na obra de Bloch, pode ser entendido ao compreender que este pensamento "estava antes tomado pelo problema do legado religioso" (Bloch, 2006b, p. 370).

Em textos como Teses provisórias para a reforma da filosofia e Essência do Cristianismo, na tentativa de afirmar o humano, o materialismo sensualista de Feuerbach faz uma crítica antropológica à religião, de modo a mostrar que aquela é a verdade desta. Assim, Ernst Bloch vê desenhar-se nesta o que ele próprio chama de uma teoria do desejo na religião, de modo a interpretar os conteúdos do "céu" em sua raiz terrena, desvendando o ser humano escondido na hipóstase Deus, mostrando a discrepância entre o homem existente e sua essência não existente, mas ainda a ser compreendida e afirmada. Nessa medida, em Feuerbach

\footnotetext{
Deus desaparece totalmente como criador do mundo, mas obtém-se um enorme âmbito de criação no ser humano, em que - mediante uma ilusão fantástica e simultaneamente uma riqueza fantástica - surge o divino como imagem do desejo humanamente hipostasiada de primeira grandeza. Essa "teoria do desejo da religião" torna-se, para Feuerbach, o mesmo que a "antropologização da religião" ou a revogação da "duplicação celestial do ser humano" (Bloch, 2006b, p. 368).
}

Em outros termos, o problema colocado para Feuerbach, como para Bloch, não é o problema da existência ou não de deus. Essa questão já teria sido resolvida pelo iluminismo. Feuerbach escreve: "Deus é o realizador, isto é, a realidade, a satisfação dos meus desejos" (Apud Bloch, 2006b, p. 370). Assim, contra a alienação realizada na objetivação da essência

\begin{tabular}{|c|c|c|c|c|}
\hline Qovista Dialectus & Ano 10 & n. 21 & Janeiro - Abril 2021 & p. $136-154$ \\
\hline
\end{tabular}


humana na essência divina - cabendo, pois, desencantar o céu para tornar o homem importante -, o elemento mais relevante apreendido por Feuerbach foi, no entender de Bloch, vislumbrar nessa duplicação do mundo, na busca de nossa "essência humana", a busca de um ser humano ideal, na recusa daquilo que o homem não é, na recusa, pois, da situação presente do homem. Desse modo, na hipóstase deus se encontraria a busca de um ser humano redimido.

Ernst Bloch concorda, com efeito, que a religião é expressão da miséria humana, miséria essa surgida não da abstração mental, mas no interior das relações sociais de produção e reprodução material da vida. Todavia, a religião aparece também como protesto contra a miséria real. Por isso, "não há crítica antropológica da religião que possa roubar a esperança sobre a qual foi aplicado o cristianismo" (Bloch, 2006b, p. 373). Em outros termos, na hipóstase "deus", presente nas religiões, habitou a esperança de um homem não mais cindido frente ao real exterior, de tal maneira que um ateísmo que meramente afirmasse a inexistência objetiva de um ens perfectissimum nada diria, em profundidade, acerca do fenômeno religioso. Nessa direção, Ernst Bloch observa que

\begin{abstract}
A intenção religiosa do reino como tal implica ateísmo, afinal compreendido. Na medida em que este não só expulsa a superstição, para colocar no seu lugar um negativum tão minguado quanto era volátil o positivum da superstição. [...] De modo que a posição designada pelo ex-Deus não é, ela mesma, um nada; isto ela seria somente se ateísmo fosse niilismo, mais precisamente, não só um niilismo da desesperança teórica, mas da destruição material-universal de todo o possível conteúdo de finalização e de perfeição (Bloch, 2006b, p. 282).
\end{abstract}

A reflexão realizada por Ernst Bloch a propósito do fenômeno religioso nos leva ao seguinte questionamento: o pensador, em particular nesta questão, não estaria caminhando na contramão do marxismo? O marxismo não já teria encerrado esse problema, concluindo que a religião - "ópio do povo" - seria mera ideologia cuja finalidade seria justificar os males existentes e apaziguar os conflitos dali decorrentes?

Ora, também no que concerne ao problema da religião, e talvez sobretudo, Bloch entrou em conflito com o marxismo vulgar. Em sua perspectiva, aliás, somente um materialismo do tipo mecânico poderia abster-se de pensar tais questões. Se a antropologia de Feuerbach chegou a refletir com certa amplitude o fenômeno religioso, tal se deu com um limite, qual seja, a desconsideração da história em processo, da sociedade, e da sensibilidade compreendida como práxis-sensível (Cf. Marx, 1996). Mesmo assim, como se estivesse a

\begin{tabular}{|c|c|c|c|c|}
\hline Qovista Dialectus & Ano 10 & n. 21 & Janeiro - Abril 2021 & p. $136-154$ \\
\hline
\end{tabular}


falar menos do materialismo de Feuerbach e, mais propriamente, do materialismo do marxismo vulgar, Ernst Bloch escreve:

\begin{abstract}
O materialismo, como explicação do mundo a partir de si mesmo, apenas na sua versão mecânica omitiu também a posição anteriormente ocupada pela hipóstase periférica "Deus"; mas ele omitiu também vida, consciência, processo, reversão de quantidade em qualidade, novum, dialética de modo geral (Bloch, 2006b, p. 283).
\end{abstract}

Nesse sentido, Ernst Bloch afirmava ser necessário uma nova antropologia da religião, uma antropologia distinta daquela de Feuerbach. Tratava-se de afirmar, no âmbito do materialismo-dialético marxista, a necessidade de compreender os conteúdos religiosos. Logo, é nessa direção que o próprio escritor tenta contribuir.

\title{
2. Thomas Münzer e a teologia da revolução: retorno ao cristianismo primitivo
}

No Thomas Münzer: teólogo da revolução, texto de juventude, surge como relevante a distinção feita por Bloch entre as seitas e a Igreja estatutária. Na história da Igreja sempre surgiram purificadores (heréticos para a Igreja) que tentaram retomar o espírito primitivo do cristianismo (Vieira, 2010, p. 41). Na leitura "herética" da Bíblia tal como intentada por Ernst Bloch - aquela que inspirou as lutas campesinas e alimentou a rebelião contra os senhores -, religião e igreja não surgem como sinônimos. Nessa distinção, Bloch reflete que enquanto a Igreja, mediante o aparelho burocrático eclesiástico, alimentou sentimentos de paciência e submissão ante os poderosos, podemos falar de um "autêntico caráter guerreiro das seitas”. Em seu Thomas Münzer, escreve:

Há propriamente diferenças sociológicas, as diferenças estruturais entre as seitas e a Igreja como tipos ideais, decisivamente claras entre a relação do mundo com o Cristo das seitas e o Cristo da Igreja [...]. Assim se faz a distinção certa: na seita se entra voluntariamente, na Igreja se nasce. [...] A seita fundamenta-se na bondade humana originária. [...] A Igreja, ao contrário, é como o Estado, baseada na corrupção originária dos homens e na necessidade de ir aos poucos de encontro a esta [...] A seita encontra os seus entre o povo pobre e oprimido, não desencaminhável pelo que se tornou homem por ele, ela reúne decididos, discípulos de Jesus que se voltam para o futuro, reúne-os a partir do mundo. [...] A Igreja, ao contrário, olha para trás, como ideologia da camada superior, faz pacto com o existente, [...] vive teologicamente nas forças do acontecido, tem atrás de si algo pronto, objetivado, um depositum Dei concluído desde o tempo dos apóstolos, depósito que promete a seus fiéis paz e segurança, que lhes limita o olhar. [...] [A Igreja é] organização fundada na divisão do trabalho (Bloch, 1973, pp. 171-172).

\begin{tabular}{|c|c|c|c|c|}
\hline Qovista Dialectus & Ano 10 & n. 21 & Janeiro - Abril 2021 & p. $136-154$ \\
\hline
\end{tabular}


Em outros termos, Bloch concorda que as igrejas sempre se coadunaram com o poder secular. As formas religiosas não dominantes como as seitas, entretanto, enquanto ruptura com o mundo existente, por vezes apresentaram-se como fenômenos protestatórios ou mesmo revolucionários, em particular quando

\begin{abstract}
Essas seitas tem um objetivo revolucionário explícito, como é o caso dos anabatistas. A guerra dos camponeses tomou em conta as aspirações não somente religiosas, mas também as sociais. Nesse sentido, ela foi até o extremo de sua própria lógica: a igualdade de todos diante de Deus implicava o fim das desigualdades econômicas e políticas (Bertrand, 1986, p. 191).
\end{abstract}

Nas entrelinhas da obra Thomas Müntzer, encontramos a afirmação, contraditória para muitos, de que há elementos utópicos na religião judaico-cristã, elementos esses que ressurgem com explosividade na experiência da revolta camponesa liderada por Thomas Münzer, o teólogo da revolução. Na tentativa de compreender a revolta anabatista entrecruzam-se temas como marxismo, religião e luta de classes. Do Thomas Müntzer a $O$ Princípio esperança, há a recusa de uma relação mecânica entre a estrutura econômica da sociedade e a esfera cultural, a qual pertence a religião. Ao fazer isso, o que o autor está a recusar é a postura típica do marxismo vulgar, no qual predominou uma empobrecida compreensão que entendia tal relação por meio de uma teoria do reflexo, concluindo quase sempre como desnecessário um tratamento mais aprofundado para o âmbito da produção cultural.

O intuito de Bloch seria, com efeito, resgatar a figura e a ação de Thomas Münzer e do movimento anabatista por ele liderado enquanto herança intacta que devia/deve ser atualizada no contexto do século XX e, em particular, para o contexto de uma Alemanha que, no período em que Bloch escrevia o texto sobre o teólogo da revolução, estava a reviver a ascensão dos movimentos revolucionários dos trabalhadores entre os anos de 1918 a 1923.

Parece claro, com efeito, que "no projeto de Bloch não reside a apologia de um passado inatual, morto, mas na afirmação da atualidade de um passado vivo, bem como na necessidade de sua apropriação política para o presente histórico" (Maciel; Vieira, 2016, p. 184). Assim, numa concepção dialética do tempo histórico, recusando a existência de um abismo que separa definitivamente passado, presente e futuro, o pensador alemão esclarece os objetivos do Thomas Münzer que surgem como um esclarecimento das próprias intenções existentes na amplitude de sua obra teórica:

Estas páginas associam à atualidade, aos dias vindouros, o prematuro movimento, meio esquecido, apenas em parte consciente. Certamente, pois, este trabalho foi

\begin{tabular}{|l|l|l|l|l|}
\hline Q Rovista Qialectus & Ano 10 & n. 21 & Janeiro - Abril 2021 & p. $136-154$ \\
\hline
\end{tabular}


elaborado em si mesmo enquanto Filosofia da religião e da História, apesar de sua base empírica. E isto ocorre porque, não só nossa vida, como tudo o que a ela diz respeito, está sempre em processo e, em consequência, não fica fechado nos limites de seu tempo ou da história em geral, exercendo sua influência, enquanto sinal de testemunho, num campo meta-histórico (Bloch, 1973, pp. 6-7).

A ideia de testemunho está indissoluvelmente associada ao que constitui a figura de Thomas Müntzer: uma herança atual para o presente histórico. Assim, do mesmo modo que Engels havia retomado a importância das guerras camponesas na Alemanha à luz dos eventos de 1848, Ernst Bloch tentou vincular o nome de Münzer aos eventos revolucionários ocorridos na Alemanha dos anos 1918-1923. Dito de outro modo, a herança intacta do profeta-revolucionário e das lutas camponesas em fins da Idade Média poderiam surgir como alimento para as lutas políticas do presente, não podendo "os vencidos" da história ser legados ao esquecimento, tal como sempre conduziram concepções da história embasadas "numa sucessão de imagens despedaçadas, [...] numa sólida epopéia do progresso” (Bloch, 1973, p. 7).

Esse duplo aspecto do fenômeno religioso é o que Bloch parece estar a abordar quando, em seu Thomas Münzer: teólogo da revolução, tematiza dois nomes que, na ocasião das revoluções camponesas em fins da Idade Média e inícios dos novos tempos que se anunciavam, atuaram de modo diametralmente oposto. De um lado, Thomas Münzer, líder do movimento anabatista; de outro, Lutero, teólogo que, perante a organização do povo nas lutas camponesas, tomou o partido dos príncipes e da nobreza feudal.

Assim, o teólogo que em $O$ Princípio Esperança vem chamado de "o revolucionário dentre os místicos” (Bloch, 2006b, p. 385), no texto de 1921 Bloch escreve que Münzer é um rebelde cristão "esquecido, desde que coubera ao vencedor escrever a história” (Bloch, 1973, p.105). Acerca dos objetivos de seu texto, é o próprio Ernst Bloch a dizer que "essas páginas associam à atualidade (...) o prematuro movimento, meio esquecido, apenas em parte consciente" (Ibid, p. 6-7).

Foi precisamente o conteúdo utópico presente na tradição bíblica - e não a sua apropriação feita pelo poder secular - que, na visão de Bloch, renasceu na atuação ao mesmo tempo religiosa e política do teólogo Thomas Münzer. No conturbado século XVI, quando se desestruturava o velho sistema feudal, os camponeses sublevaram-se contra a situação de miséria extrema. Sobre a radicalidade do movimento anabatista e sua relevância política para a história posterior das lutas operário-camponesas, Friedrich Engels afirma que

\begin{tabular}{|l|l|l|l|l|}
\hline Q Rovista Qialectus & Ano 10 & n. 21 & Janeiro - Abril 2021 & p. $136-154$ \\
\hline
\end{tabular}


$\mathrm{Na}$ Alemanha foram Thomas Münzer e seu partido os que primeiro a levaram a cabo. [...] No caso de Münzer esses brotos do comunismo expressavam as aspirações de toda uma fração da sociedade; desde que ele os formulou pela primeira vez com certa clareza, encontramo-los em todos os grandes movimentos populares, até que por fim se uniram ao movimento proletário moderno; tal como na Idade Média, as lutas dos camponeses contra a dominação feudal, cada vez mais ameaçadora, uniu-se com a luta dos vassalos e servos pela destruição total dessa dominação (Engels, 1977, p. 42).

Naquilo que Ernst Bloch denomina como espírito da "autêntica reforma" (Bloch, 1973, pp. 53-54), Thomas Münzer opôs-se ao mundo profano, ao poder secular, e às desigualdades sociais por ele produzidas. O reino de deus, na visão do profeta, devia ser construído pela cristandade e, sobretudo, tratava-se de uma escatologia que anunciava um reino de Deus na terra. Em suas pregações, Münzer anunciava a necessidade de destruir os privilégios de classe, como pode ser observado na passagem abaixo do sermão Muito bem fundada apologia e resposta a esta carne sem espírito que leva boa vida em Wittemberg e que, virando tudo pelo avesso, trancando a Santa Escritura, enxovalhou de maneira tão desoladora a miseranda cristandade:

\footnotetext{
Se a autoridade quiser pronunciar uma sentença injusta, então devem os cristãos rejeitá-la e não suportá-la, pois deus exige contas do sangue inocente derramado. A maior infâmia da terra consiste em que ninguém quer tomar para si a miséria do pobre; os grandes deste mundo agem como querem. Eis, pois, o auge da avareza, do sonho e da pilhagem dos nossos príncipes e senhores: apossam-se de toda criatura, sejam peixes n'agua, aves no céu ou plantas na terra; tudo deve ser seu. Em seguida espalham o mandamento de deus entre os pobres, e dizem: Deus ordenou que não roubeis! Contudo, não acharam uso deste mandamento para si mesmos. [...] Assim, quem quer que agarre o menos que seja, deve ser enforcado, e o Doutor Mentiroso diz logo amém (Münzer Apud Bloch,1973, p. 38).
}

No fragmento acima delineia-se o radicalismo político de Thomas Münzer, que chegou a propagar em seus sermões a impossibilidade de destruir os privilégios sem estabelecer igualdade e justiça. O teólogo da revolução parece, com efeito, associar a miséria do povo à existência da propriedade privada bem como sua concentração nas mãos de uma minoria. Martinho Lutero, a quem o próprio Müntzer havia apoiado entre os anos de 1517 a 1522 em sua atitude de opor-se à Igreja romana, por outro lado, havia tomado "o partido dos vencedores" (Bloch, 1973, p. 29). Diante do perigo da revolução popular todos os antigos opositores haviam se unido, príncipes e latifundiários, fossem luteranos ou católicos. É o próprio Lutero que conclama aos príncipes a usar suas armas contra os anabatistas:

Eis porque, Alteza, não se deve mais nem dormir, nem negligenciar, pois Deus exigirá as contas, e quer ter resposta, a respeito de um tal descaso no sério uso da espada admitida. Do mesmo modo, não seria perdoável também diante das pessoas e

\begin{tabular}{|l|l|l|l|l|}
\hline Govista Qialectus & Ano 10 & n. 21 & Janeiro - Abril 2021 & p. $136-154$ \\
\hline
\end{tabular}


do mundo, que sua alteza tolerasse o punho subversivo e audacioso (Lutero, Apud Bloch,1973, p. 29).

Lutero diz ainda neste texto que "Chegaram os miraculosos tempos em que um príncipe pode melhor merecer o céu, derramando sangue, que outros com orações” (Ibid, p. 103).

Na figura de Lutero, portanto, eis o antípoda da atitude de Münzer e expressão de uma religião disposta a justificar e legitimar a ordem existente. Entre Lutero e Münzer, com efeito, encontramos duas apropriações completamente distintas do legado cristão, legado esse que, originalmente perseguido pelo império romano, tornou-se religião do império numa Igreja que havia se transformado, "voluntária ou involuntariamente, insubstituível para os ricos com o fim de apascentar os escravos, amenizar as terríveis desgraças, assimilar em si toda possível revolta" (Bloch, 1973, p. 148). O cristianismo de Estado que Lutero havia outrora condenado foi precisamente seu ponto de chegada. No contexto do calvinismo, indo ainda mais longe, culmina-se numa paz prematura com o mundo existente, de modo a fundar uma nova religião, a "religião de Mamon", a religião do deus dinheiro, tal como representou a

Fé burguesa de Calvino, na sua concordância diante do diabólico mandamento mundano, $[\ldots]$ numa reforma que não representa enfim mero abuso do cristianismo, e sim contém elementos de uma nova 'religião': do capitalismo, tornada, em consequência, religião e igreja de Mamon (Bloch,1973, p. 120).

A Alemanha do século XVI havia conhecido "a mais perigosa rebelião que defrontou até a primeira guerra mundial" (Ibid, p. 105). Da união das forças de direita resultou o massacre de cem mil camponeses e proletários, dentre eles o próprio Münzer, líder do acontecimento que representou, segundo Marx, o mais radical da história alemã. No contexto cultural alemão no século XX, o nome de Thomas Münzer ressurgiu precisamente no contexto da revolução alemã, ou seja, numa história cronologicamente próxima de nós e distante dos tempos em que Münzer viveu.

É, pois, no contexto de um tempo distópico que passou a conhecer o aguçamento do irracional na história que o projeto de Ernst Bloch foi o de levar, para o âmbito do pensamento marxista, a apropriação das utopias para o âmbito de um pensamento com a pretensão de fazer a crítica do presente. Desse modo, tentando uma ampliação do marxismo com ênfase no âmbito da cultura, o pensamento de Ernst Bloch apresenta a necessidade de uma apropriação crítica dessa herança cultural intacta. As utopias, com efeito, tal como a presente no cristianismo primitivo, serão sempre expressão da tensão que se estabelece entre 
as aspirações e desejos, e a realidade, questionando o mundo existente ao projetar um tempo futuro livre da opressão. Na concepção do autor,

Não basta uma pura reflexão econômica para, sozinha, explicar as condições e as causas da erupção de um acontecimento histórico com a violência da guerra camponesa, bem como, pois, uma tal análise seria capaz de dissolver, de destruir, o conteúdo profundo dessa história humana, aqui tão ardente, desperto desse sonho, que almejava uma sociedade onde o homem não fosse o lobo do homem, num império enfim fraternal, ao despojá-lo do seu caráter originário, tornando-o irreal, ao convertê-lo em pura ideologia (Bloch,1973, p. 48).

Desta feita, no nome de Thomas Münzer poderíamos dizer que Bloch vislumbra o encontro entre o judaísmo e o cristianismo primitivo, tal como o representado pelo teólogo da revolução: o messianismo como sinônimo de ruptura com o existente dado. Para o autor do Thomas Münzer, tal elemento deve ser buscado, em primeiro lugar, no Antigo testamento, numa Bíblia subterrânea que foi, certamente, corrompida pelas instituições religiosas associadas ao poder. Todavia, a religião de Estado não conseguiu apagar tais elementos subversivos presentes na Bíblia, elementos que renasceram em vários momentos ao longo da história.

\section{O ateísmo no cristianismo}

Em $O$ ateísmo no cristianismo, à luz do jargão comumente repetido por parcela da tradição marxista acerca do fenômeno da religião, Bloch questiona: "O ópio do povo: isso é tudo?” (Bloch, 1978, p. 78). Aliás, ainda quanto ao tema relativo à religião, o autor insiste, mais uma vez, em lembrar a influência de Hegel e Feuerbach para o marxismo:

\footnotetext{
Não há em Marx nenhum vestígio dessa ingenuidade a-histórica, pois entre ele e os enciclopedistas encontramos Hegel e Feuerbach. Em particular esse último, com sua teoria dos desejos, sua teoria da duplicação do mundo e sua teoria da alienação na religião: não foi para enganar que a religião foi criada, ela nasceu de uma ilusão que o espírito não poderia superar (Bloch, 1978, p. 79).
}

Nesse comentário de Bloch, encontramos a relevância por ele dada ao texto de Marx Introdução à crítica da filosofia do direito de Hegel. Em O Princípio esperança, em oposição a parcela do marxismo vulgar - aquela que renegou as obras de juventude como textos de um Marx ainda idealista, ainda mero "filósofo", obras distantes da cientificidade da obra madura, "econômica" -, o autor compreende que "no mais tardar, a partir de 1843, Marx tornou-se materialista" (Bloch, 2005, p. 249). Ou seja, em um texto de juventude de Marx

\begin{tabular}{|c|c|c|c|c|}
\hline Qovista Dialectus & Ano 10 & n. 21 & Janeiro - Abril 2021 & p. $136-154$ \\
\hline
\end{tabular}


como o acima citado, a crítica do céu já havia se transformado na crítica da terra, de modo a já haver superado o idealismo, mesmo o idealismo materialista de Feuerbach. Assim, em $O$ ateísmo no cristianismo, Bloch repete o texto de Marx:

A religião é a realização imaginária da essência humana porque o ser humano não possui uma verdadeira realidade ... A miséria religiosa é, de um lado, expressão da miséria real e, ao mesmo tempo, protestação contra a miséria real. A religião é o suspiro da criatura desesperada, a alma de um mundo sem coração tanto quanto o espírito de um mundo abandonado pelo espírito. Ela é o ópio do povo (Bloch, 1978, p. 81).

A reflexão acerca da religião ocupa lugar central nos escritos de juventude de Marx, o que não ocorrerá em sua obra tardia. Entretanto, isso não significa que o pensador alemão abandonou o problema na totalidade de sua obra, estando inserido no interior da questão relativa à ideologia. Para Bloch, se, de um lado, o fato da crença, da religião, é um fato subjetivo, isto não significa que sua origem deva ser buscada unicamente no âmbito subjetivo. Ao contrário, em sua origem, deita suas raízes no interior das relações sociais de produção.

A reflexão realizada por Bloch acerca do vínculo a ser pensado entre marxismo e religião permeia a relação e a distinção estabelecida entre ideologia e função utópica no que concerne ao tema da religião. É essa dimensão utópica que, para o autor, deve ser compreendida. No pensamento de Ernst Bloch, em cuja leitura assistimos a recusa da oposição comumente estabelecida (por todos os "partidos") entre ateísmo e religião, fé e revolução, há uma (re) leitura política da tradição bíblica judaico-cristã. Para o autor de Herança dessa época, há uma dimensão utópica no interior dessa tradição. Em seu entender, trata-se de "uma fé eminentemente histórica" (Bloch, 2006b, p. 323), de modo que seu conteúdo ultrapassa as limitações do presente e projeta-se no futuro: "nas hipóstases dos deuses, seres humanos jamais expressaram nada mais que o futuro ansiado, um futuro que obviamente só pode ser apreendido de modo ilusório nessas hipóstases” (Ibid, p. 274).

Ao tratar o tema relativo à utopia na religião, Bloch realiza uma crítica a certa tradição ateísta e materialista mecânica que tratou "os conteúdos religiosos como se estes [...] fossem um mero nada" (Ibid, p. 283). Ao fazer isso, o pensador alemão estava, evidentemente, recusando a perspectiva teórica predominante na tradição marxista. $\mathrm{O}$ materialismo vulgar com que estes olharam os fenômenos da superestrutura mostraram mais estreiteza, certamente, ante o ambíguo e complexo fenômeno da religião. Para o pensamento dialético, Bloch reclama com insistência em várias de suas obras a compreensão da utopia presente na religião. Como escreve no terceiro volume de $O$ Princípio Esperança,

\begin{tabular}{|c|c|c|c|c|}
\hline Qevista Dialectus & Ano 10 & n. 21 & Janeiro - Abril 2021 & p. $136-154$ \\
\hline
\end{tabular}


O materialismo autêntico, o dialético, anula justamente a transcendência e a realidade de toda hipóstase de Deus, sem, no entanto, eliminar dos conteúdos qualitativos finais do processo, da utopia real de um reino da liberdade, o que se tem em vista com um ens perfectissimum. [...] A existência de Deus, sim, Deus de um modo geral como um ente é superstição; fé é unicamente a voltada para o reino de Deus messiânico - sem Deus. Em consequência disso, o ateísmo é tão pouco inimigo da utopia religiosa que constitui o pressuposto desta: sem o ateísmo o messianismo não tem lugar (Bloch, 2006b, p. 283).

Conforme explicita Bloch em O ateísmo no cristianismo, a crítica de Marx à religião direciona-se à forma institucionalizada tal qual representaram/representam as igrejas, criticando-as em sua função claramente ideológica, ou seja, como ópio do povo ou, falando em termos mais comumente aceitos pelo marxismo dominante: em sua forma institucionalizada, as religiões cumpriram e cumprem o papel de selar a pacificação e a harmonização com a sociedade existente. Desta feita, apenas um materialismo vulgar poderia compreender os fenômenos ideológicos - nesse caso a religião - como mera fantasia, como algo irreal. De fato, trata-se o fenômeno religioso de um fenômeno real, cuja existência deve ser entendida e vinculada ao mundo dos homens no processo de produção e reprodução da vida, reprodução material e também espiritual:

Marx compreendeu e desvendou a função eminentemente ideológica da Igreja. [...] A crítica da religião encontra em Marx toda a força que ela tinha na época das Luzes: sua atitude de ligar a névoa do céu à ideologia geradora de ilusões, de ilusões que não são voluntárias, subjetivas - uma tese insustentável para os tempos antigos -, mas objetiva e decorrente de uma necessidade social (Bloch, 1978, p. 79).

Assim, a tese "marxista" que afirma ser a religião o ópio do povo, quando associada à sua forma institucionalizada, ou seja, às igrejas, constitui "uma das grandes ideias do marxismo" (Bloch, 1978, p. 80). Para Ernst Bloch, contudo, é necessário recusar o ateísmo vazio, em particular o ateísmo presente no marxismo vulgar, a medida de seu reducionismo ao entender na afirmação "a religião é o ópio do povo" uma verdade tão incontestável e universal a ponto de negar a necessidade de uma maior compreensão do fenômeno religioso, entendendo neste um fenômeno mais complexo. Como escreve em $O$ ateísmo no cristianismo,

Se o ateísmo do marxismo vulgar, tal como o ateísmo burguês, se torna um lugarcomum, o ateísmo marxista, liberto, fora da negação, possui um horizonte mais distante. E nós poderíamos mesmo dizer que mesmo os lugares-comuns transcorridos no marxismo conservam sempre quanto à religião sua potencialidade crítica, sua oposição à alienação, via Marx e Feuerbach (Bloch, 1978, p. 80).

\begin{tabular}{|l|l|l|l|l|}
\hline Q Povista Qialectus & Ano 10 & n. 21 & Janeiro - Abril 2021 & p. $136-154$ \\
\hline
\end{tabular}


Na relação que se estabelece entre religião, política e luta de classes, Ernst Bloch não nega, com efeito, o papel que historicamente a religião teve e tem ainda no sentido de legitimação do mundo existente e de justificação do poder dominante. $\mathrm{O}$ desejo do cristianismo primitivo de uma comunidade utópico-cristã foi, de fato, destruído pela consolidação da Igreja estatutária, historicamente defensora do status quo (Vieira, 2010, p. 41). Todavia, é preciso compreender dialeticamente esse fenômeno, de modo a fazer um "uso diabólico" daquele aspecto que surge como conteúdo do desejo que recusa o existente dado e projeta seus conteúdos no futuro, na dimensão bíblica do "eis que faço novas todas as coisas", no deus de Isaías que diz: "vou criar novo céu e nova terra; assim, o passado não será mais lembrado" (Isaías, 65,17).

Por esse motivo, nas linhas do texto de Bloch, apresenta-se o chamado a uma leitura "herética" da Bíblia, quer dizer, uma leitura que, opondo-se à interpretação "oficial" das igrejas, busca resgatar uma herança bíblica que existiu/renasceu com Joaquim de Fiori (1135-1202), em sua visão mística e apocalíptica do mundo, defendendo que a comunidade ideal derivaria na própria estrutura histórica, isto é, que as mudanças sociais deveriam ocorrer na própria história humana (Vieira, 2010, p. 42). Cabe destacar que o nome de Joaquim de Fiori é demasiadamente caro a Ernst Bloch. O filósofo alemão cita o nome do monge calabrês como representando "a utopia social de maior impacto na Idade Média. [...] Seu propósito não era purificar a Igreja, nem mesmo o Estado, de suas atrocidades, mas sim aboli-los" (Bloch, 2006a, p. 64).

No cristianismo professado por Joaquim, o esperado reino de Deus realizar-se-ia na terra, implantando uma democracia mística, na qual não mais haveria senhores, nem Igreja, nem ricos e pobres, ou seja, haveria a ausência de propriedade. A importância do cristianismo joaquimita perdurou por séculos, em seitas russas e nas revoltas camponesas em fins da Idade Média, como os hussitas e os taboritas, valendo ressaltar a influência em Thomas Münzer, bastante tempo depois, chegando mesmo, direta ou indiretamente, aos socialistas utópicos do século XIX. Em suma, para Bloch o cristianismo joaquimita, em sua radicalidade utópica, é herança intacta também a ser preservada e atualizada no tempo presente, pois "representa forçosamente o espírito da utopia social cristã revolucionária: desse modo ele ensinou e continuou influindo" (Bloch, 2006a, p. 67).

Nas experiências religiosas críticas ocorridas em terras tupiniquins, será que não estamos a falar em um reavivamento/releitura de um cristianismo tal como o apropriado por

\begin{tabular}{|l|l|l|l|l|}
\hline Govista Qialectus & Ano 10 & n. 21 & Janeiro - Abril 2021 & p. $136-154$ \\
\hline
\end{tabular}


Thomas Münzer, o teólogo da revolução? Aqui poderíamos citar a subversiva comunidade de Canudos, ou também a leitura bíblica como a que fundamentou a Teologia da Libertação na América Latina no justo momento histórico em que ditaduras militares foram adotadas pelas elites - e apoiadas pelas burocracias eclesiásticas - como mais eficazes para manter o status quo.

A reflexão blochiana entende, na história das religiões, a existência de um grito contra o sofrimento e a expectativa de um mundo e de um homem melhor. Daí sua afirmação: “onde há esperança, há religião" (Bloch, 2006b, p. 276). É no judaísmo e no cristianismo que o pensador alemão encontra experiências religiosas que - de forma radical e como nenhuma religião anterior havia realizado - refutaram o existente, de tal modo que o filósofo os aponta “como as religiões mais elevadas" (Bloch, 2006b, p. 284). Para Bloch, a tradição mosaica é sempre marcante dessa radicalidade e novidade que o judaísmo deixa de herança ao cristianismo, posto que um salto na consciência religiosa "que foi preparado por um evento que consiste na coisa mais oposta possível às religiões pregressas. [...] Foi preparado pela rebelião, pela retirada do Egito" (Ibid, p. 316). É nesse aspecto, com efeito, que se inscreve o messianismo: “já em Moisés estava implantado o Deus spes, mesmo que a imagem de um líder derradeiro para fora do Egito, ou seja, do Messias, surja só mil anos mais tarde; o messianismo é mais antigo do que essa fé no Messias" (Ibid, p. 321). Aqui, com efeito, Bloch argumenta juntamente a seu antigo amigo, o sociólogo Max Weber:

O aspecto peculiar da expectativa israelita é a intensidade crescente com que foi projetado para dentro do futuro, seja o paraíso, seja o rei salvífico, o primeiro a partir do passado, o segundo a partir do presente. Isso não ocorreu apenas em Israel; mas em nenhum outro lugar essa expectativa ocupou o centro da religiosidade com a mesma impetuosidade, e que, pelo visto, aumentava gradativamente. O antigo Berit (pacto) de Javé com Israel, a sua promessa em conexão com a crítica do presente miserável é que possibilitou isso; mas foi a impetuosidade da profecia que fez de Israel um povo da expectativa e da perseverança nessas proporções singulares (Ibid, p. 321).

É o próprio Engels, numa clara associação entre política, religião e luta de classes que, de certo modo, às vezes desenvolve em termos que se aproximam bastante dos próprios termos como Bloch trata o movimento religioso-revolucionário. Nessa perspectiva, é válido reproduzir o longo fragmento de Engels a propósito da "pregação" de Thomas Münzer:

Sua doutrina política procede diretamente de seu pensamento religioso revolucionário. [...] Se a filosofia religiosa de Münzer se aproximava do ateísmo, seu programa político tinha afinidade com o comunismo. Muitas seitas comunistas modernas, em vésperas da revolução de fevereiro, não dispunham de arsenal teórico 
tão rico como “os de Münzer" do século XVI. [...] Tal programa exigia o estabelecimento imediato do reino de Deus, do reino milenário de felicidade, tantas vezes anunciado pela volta da Igreja à sua origem e pela supressão de todas as instituições que se achassem em contradição com esse cristianismo que se dizia primitivo e que em realidade era altamente moderno. Porém, segundo Münzer, esse reino de Deus não significava outra coisa senão uma sociedade sem diferenças de classe, sem propriedade privada e sem poder estatal independente e alheio aos membros da sociedade (Engels, 1977, pp. 48-49).

Para Bloch, o sonho judaico de chegar a Canãa deve caminhar menos na direção do sionismo e mais na direção do judeu Karl Marx, que de modo algum foi sionista. Justamente nesse problema milenar não solucionado, Ernst Bloch aponta em seu texto a atualidade da utopia concreta existente nas linhas do pensamento do filósofo Marx. Parece se desenhar no texto de Bloch a memória de Sobre a questão judaica, quando seu autor, sempre muito disposto a um embate político, entrou em linha de colisão com Bruno Bauer, pois este, em sua visão, havia reduzido o problema da emancipação política dos judeus a uma questão puramente religiosa. Para Marx, tratava-se não somente de recusar o Estado cristão e exigir o Estado laico (tal qual faz Bauer, como requisito para a emancipação política dos judeus), mas de se fazer a crítica do Estado, da necessidade de transformar a questão judaica numa crítica de toda a sociedade, à medida que, no entender do grande pensador do século XIX, o problema judeu possuiria um fundo social que é o motivo real de sua existência: "Vemos o erro de Bauer no fato de submeter à crítica tão somente o "Estado cristão", mas não o "Estado como tal", no fato de não investigar a relação entre emancipação política e emancipação humana" (Marx, 2010, p. 76). Em suma, talvez Bloch resgate uma antiga pergunta: reforma social ou revolução? A resposta a tal questão representa uma tentativa, em seu pensamento, de resgatar o marxismo como uma utopia concreta. É no mesmo sentido que o pensador de Ludwigshafen utiliza as expressões filosofia do futuro e filosofia da revolução para caracterizar o marxismo.

\section{Considerações finais}

Em sua investigação filosófica, Ernst Bloch busca pensar a relação entre religião, política e luta de classes. $\mathrm{O}$ autor não nega o papel que historicamente a religião teve, e ainda tem, no sentido de legitimação do mundo existente e de justificação do poder dominante. É necessário, todavia, compreender dialeticamente esse fenômeno, de modo a fazer um "uso diabólico" daquele aspecto que surge como conteúdo do desejo que recusa o existente dado e projeta seus conteúdos no futuro. A propósito da abordagem do cristianismo tal como

\begin{tabular}{|l|l|l|l|l|}
\hline Q evista Dialectus & Ano 10 & n. 21 & Janeiro - Abril 2021 & p. $136-154$ \\
\hline
\end{tabular}


realizada pelo pensador aqui abordado, é esclarecedora a seguinte afirmação de Suzana Albornoz:

\begin{abstract}
Na versão blochiana, a crítica do cristianismo feita por Marx não atinge a Igreja de Joaquim [de Fiori] e de Münzer. Esta crítica, se contemporânea, teria sido bem aceita por Joaquim, como também pelos albigenses, hussitas e anabatistas, pois todos lutaram contra os princípios sociais do cristianismo adaptado a uma sociedade de classes. A resignação ao medo, à servidão e à promessa do "outro mundo" são tais princípios sociais, objeto do desprezo de Marx como de Joaquim e de Bloch. Não são estes os princípios do cristianismo primitivo nem da história sóciorevolucionária considerada herética que se lhe seguiu (Albornoz, 1995, p. 82).
\end{abstract}

Tal como o autor desenvolve em sua obra máxima, os sonhos com valor utópico prospectam em torno de um mundo redimido. Nas experiências dos movimentos heréticos ao longo da história do cristianismo, o que de modo algum esses movimentos quiseram foi estabelecer uma paz prematura com o mundo existente. Ao contrário, a redenção e a espera do reino de Deus somente se daria mediante uma ruptura apocalíptica. Nessa perspectiva, a utopia presente na religião judaico-cristã tratava-se de uma herança intacta a ser apropriada pelo marxismo como teoria crítica visando a ruptura com a sociedade presente.

Ernst Bloch tem claro, com efeito, o perigo que foi e ainda é representado por uma apropriação reacionária dessa tradição, uma apropriação feita pelo poder, uma utilização reacionária realizada pelas igrejas em nome da justificação e legitimação da ordem do mundo existente, visando "a apologia das relações de poder existentes" (Bloch, 2006b, p. 324). Tal como escreve Frank Paul acerca da reflexão bloquiana sobre a utopia na religião, Bloch “apresenta uma análise do judaísmo e do cristianismo, e de sua história, onde o objetivo é determinar sua contribuição à utopia-esperança ativa na história” (Bolwman, 1976, p. 193).

Desta feita, essa fé histórica e utópica expressa no messianismo judaico-cristão, que alimentou inúmeros movimentos de viés contestatório ao longo da história, que alimentou “a revolução de 1525, a primeira Revolução Alemã, a guerra dos camponeses" (Bloch, 2006, p. 65), na visão de Bloch, deveria ser compreendida e apropriada pelo marxismo crítico. Aliás, tais experiências seriam fundamentais na recusa ao marxismo vulgar, na medida em que apontam o alvo almejado: o reino de Deus. Ora, o que o próprio movimento cristão anabatista havia ensinado é que a redenção não virá como continuidade - na perspectiva, por exemplo, de um evolucionismo histórico tal como o que predominou no marxismo vulgar -, mas como ruptura apocalíptica ou, como disse Bloch em suas lições sobre Hegel, como “destruição que abre caminho ao novo" (Bloch, 1963, p.97).

Em outros termos, se a explicação científica é inestimável no processo revolucionário, este não pode prescindir do espírito da utopia, que não somente é alimento da

\begin{tabular}{|l|l|l|l|l|}
\hline Rovista Dialectus & Ano 10 & n. 21 & Janeiro - Abril 2021 & p. 136-154
\end{tabular}


luta revolucionária, como também sempre apontou para a meta a ser alcançada. É nessa valoração das imagens utópicas ao longo da história que a utopia na religião aparece como fulcral na obra de Ernst Bloch, sendo, como vimos, objeto de vários de seus trabalhos.

\section{Referências}

ALBORNOZ, Suzana. O enigma da Esperança: Ernst Bloch e as margens da história do espírito. Petrópolis, RJ: Vozes, 1995.

BERTRAND, Michèle. La question de la croyance: de Marx a Feuerbach. IN: GOETHE INSTITUT. Ernst Bloch et Györg Lukács: un siècle après (Actes du colloque Goethe Institut, 1985). Paris : Actes Sud, 1986, p.185-196.

BLOCH, Ernst. El pensamiento de Hegel [1949]. Trad. Wenceslao Roces. Mexico; Buenos Aires: Fondo de Cultura Economica, 1963.

BLOCH, Ernst. Thomas Münzer, Teólogo da Revolução [1921]. Trad. Vamireh Chacon e Celeste Aída Galeão. Rio de Janeiro: Tempo Brasileiro, 1973.

BLOCH, Ernst. L'Athéisme dans le christianisme [1968]. Trad. Paris: Gallimard, 1978.

BLOCH, Ernst. O Princípio Esperança. Vol. I [1954]. Trad. Nélio Schneider. Rio de Janeiro: EdUERJ; Contraponto, 2005.

BLOCH, Ernst. O Princípio Esperança. Vol. II [1955]. Trad. Werner Fuchs. Rio de Janeiro: EdUERJ; Contraponto, 2006a.

BLOCH, Ernst. O Princípio Esperança. Vol. III [1959]. Trad. Nélio Schneider. Rio de Janeiro: EdUERJ; Contraponto, 2006b.

BLOCH, Ernst. Du rêve à l'utopie: Entretiens philosophiques. Textos escolhidos e prefaciados por Arno Münster. Paris: Hermann, 2016.

BOWMAN, Frank L. Ernst Bloch et l'escatologie. IN: RAULET, Gérard (Org.). Utopiemarxisme selon Ernst Bloch: un système de l'inconstructible. Payot: Paris, 1976, p. 193204.

ENGELS, Friedrich. As guerras camponesas na Alemanha [1850]. Equipe de trad. Editorial Grijalbo: São Paulo, 1977.

FEUERBACH, Ludwig. Teses provisórias para a reforma da filosofia. IN: Princípios da filosofia do futuro [1843]. Lisboa: Edições 70, 2002.

FEUERBACH, Ludwig. A Essência do Cristianismo [1841]. Trad. José da Silva Brandão. Petrópolis: Vozes, 2007.

\begin{tabular}{|c|c|c|c|c|}
\hline Qovista Dialectus & Ano 10 & n. 21 & Janeiro - Abril 2021 & p. $136-154$ \\
\hline
\end{tabular}


HARTWEG, Frédéric. Thomas Münzer, théologien de la révolution. IN: RAULET, Gérard (Org.). Utopie-marxisme selon Ernst Bloch: un système de l'inconstructible. Payot: Paris, 1976, p. 205-221.

MACIEL, Marta M. A. Do romantismo revolucionário ao marxismo: política e cultura no pensamento de Ernst Bloch. Tese de Doutorado. João Pessoa: Programa de Pós-Graduação em Filosofia UFPB/UFPE/UFRN, 2018.

MACIEL, Marta M. A.; VIEIRA, A. R. A tematização do futuro no pensamento de Ernst Bloch ou a crítica às filosofias do passado. In SOUZA, Ricardo Timm e RODRIGUES, U. M. (Orgs.). Ernst Bloch: atualidade das utopias concretas. Vol I. Porto Alegre, Editora Fi, 2016, p. 178-203.

MARX, Karl. Teses sobre Feuerbach. IN: A Ideologia Alemã (Feuerbach) [1845-1846]. 10. ed. Trad. José Carlos Bruni e Marco Aurélio Nogueira. São Paulo: HUCITEC, 1996.

MARX, Karl. Sobre a questão judaica [1844]. Apresentação e posfácio de Daniel Bensaïd. Trad. Nélio Schneider. São Paulo: Boitempo, 2010.

VIEIRA, Antonio Rufino. Marxismo e libertação: estudos sobre Ernst Bloch e Enrique Dussel. São Leopoldo: Nova Harmonia, 2010.

\begin{tabular}{|c|c|c|c|c|}
\hline Qovista Dialectus & Ano 10 & n. 21 & Janeiro - Abril 2021 & p. $136-154$ \\
\hline
\end{tabular}

